\title{
Development of Donor Recipient Chimeric Cells of bone marrow origin as a novel approach for tolerance induction in transplantation
}

\author{
Joanna Cwykiel $^{1,2}$, Maria Madajka-Niemeyer ${ }^{2}$, Maria Siemionow ${ }^{1,2,3}$ \\ ${ }^{1}$ Department of Orthopaedics, University of Illinois at Chicago, Chicago, IL, USA; ${ }^{2}$ Department of Plastic Surgery, Cleveland Clinic, Cleveland, \\ Ohio, USA; ${ }^{3}$ Department of Surgery, Poznan University of Medical Sciences, Poznan, Poland \\ Contributions: (I) Conception and design: M Siemionow; (II) Administrative support: None; (III) Provision of study materials or patients: None; (IV) \\ Collection and assembly of data: J Cwykiel, M Madajka-Niemeyer; (V) Data analysis and interpretation: J Cwykiel, M Madajka-Niemeyer; (VI) \\ Manuscript writing: All authors; (VII) Final approval of manuscript: All authors. \\ Correspondence to: Maria Siemionow, MD, PhD, DSc. Department of Orthopaedics, University of Illinois at Chicago, Molecular Biology Research \\ Building, 900 S. Ashland Ave. Room\# 3356, Chicago, IL 60607, USA. Email: siemiom@uic.edu.
}

Background: Cell therapies and chimerism-based strategies are currently the most successful approach for tolerance induction in transplantation. This study aimed to establish and characterize novel Donor Recipient Chimeric Ccell (DRCC) therapy of bone marrow (BM) origin presenting donor-recipient phenotype to support tolerance induction.

Methods: Ex vivo fusions of fully MHC-mismatched BM cells from ACI (RT1 $\left.{ }^{a}\right)$ and Lewis $\left(\mathrm{RT}^{1}\right)$ rats were performed using polyethylene-glycol (PEG). The creation of rat DRCC was tested by flow cytometry (FC), confocal microscopy and PCR. FC characterized DRCC's phenotype (CD3, CD4, CD8, CD45, CD90, CD11b/c, CD45RA, OX-82, or CD4/CD25) and apoptosis, while mixed lymphocyte reaction assessed DRCC's immunogenicity and colony forming unit assay tested DRCC's differentiation and proliferation. DRCC's polyploidy was evaluated using Hoechst33342 staining and COMET assay tested genotoxicity of fusion procedure. ELISA analyzed the secretion of IL-2, IL-4, IL-10, TGFß1, IFN $\gamma$ and TNF $\alpha$ by DRCC at day 1, 5 and 14 post-fusion. The DRCC's phenotype after long-term culturing was assessed by reversetranscription PCR.

Results: The chimeric state of DRCC was confirmed. Fusion did not change the expression of hematopoietic markers compared to BM controls. Although an increased number of early and late apoptotic (Annexin $\mathrm{V}^{+}$/Sytox blue ${ }^{-}$and Annexin $\mathrm{V}^{+} /$Sytox blue ${ }^{+}$, respectively) DRCC was detected at $24 \mathrm{~h}$ postfusion, the number significantly decreased at day $5(38.4 \% \pm 3.1 \%$ and $22.6 \% \pm 2.5 \%, v s .28 .3 \% \pm 2.5 \%$ and $13.9 \% \pm 2.6 \%$, respectively, $\mathrm{P}<0.05$ ). DRCC presented decreased immunogenicity, increased expression of IL10 and TGF $\beta 1$ and proliferative potential comparable to BM controls. The average percentage of tetraploid DRCC was $3.1 \% \pm 0.2 \%$ compared to $0.96 \% \pm 0.1 \%$ in BM controls. The lack of damage to the DRCC's DNA content supported the DRCC's safety. In culture, DRCC maintained proliferation for up to 28 days while preserving hematopoietic profile.

Conclusions: This study confirmed feasibility of DRCC creation via ex vivo PEG mediated fusion. The created DRCC revealed pro-tolerogenic properties indicating potential immunomodulatory effect of DRCC therapy when applied in vivo to support tolerance induction in solid organ and vascularized composite allograft transplantation.

Keywords: Donor recipient chimeric cell (DRCC); transplantation; cell fusion; cell therapy; immunomodulation

Received: 29 October 2020; Accepted: 03 March 2021; Published: 19 April 2021.

doi: $10.21037 /$ sci-2020-044

View this article at: http://dx.doi.org/10.21037/sci-2020-044 


\section{Introduction}

Despite the effort to optimize immunosuppression (IS) protocols, the morbidity associated with immunosuppressants significantly reduces transplant recipient's lifespan. Up to-date, bone marrow transplantation (BMT)/hematopoietic stem cell transplantation and induction of mixed chimerism remain the most successful approach for tolerance induction (1). However, BMT requires recipient's conditioning excluding some of the patients in need of allotransplantation. Experimental and clinical BMT studies reported presence of donor/recipient cells and suggested their contribution to regeneration and immune response (2-14).

Cell fusion, an ubiquitous process of asexual merging of two or more parental cells $(15,16)$, was shown to change the morphology and to reprogram the function of resulting hybrids (2). Hybrids presented increased migratory activity $(17,18)$, proliferation (17) and drug resistance $(19)$ as well as mixed phenotype and expression patterns $(20,21)$. Based on these studies we aimed to develop a novel Donor Recipient Chimeric Cell (DRCC) therapy via ex vivo fusion of bone marrow cells (BMC) from transplant donor and recipient. The proposed approach of DRCC presenting mixed donor/ recipient phenotype aims to create cell therapy offering decreased immunogenicity while improving DRCC engraftment and supporting tolerance induction.

This study focused on establishing and in vitro characterization of DRCC as well as comparison of DRCC with the naive $\mathrm{BMC}$ in preparation for preclinical testing in solid organ and Vascularized Composite Allotransplantation (VCA) models as a basis for potential future clinical application.

We present the following article in accordance with the ARRIVE reporting checklist (available at http://dx.doi. org/10.21037/sci-2020-044).

\section{Methods}

\section{BMC isolation}

Institutional Animal Care and Use Committee (IACUC) of Cleveland Clinic, Cleveland, Ohio approved this study (License number: 2012-0841). Cleveland Clinic IACUC is accredited by the American Association for the Accreditation of Laboratory Animal Care (AAALAC). All animals received humane care in compliance with the 'Principles of laboratory animal care' formulated by the National Society for Medical Research and the 'Guide for the care and use of laboratory animal resources' published by the US National Institute of Health.
BMC were isolated from femurs and tibias harvested from randomly selected 7-8-week old male ACI (RT1 ${ }^{\text {a }}$, $\mathrm{n}=30$ ) and Lewis $\left(\mathrm{RT} 1^{1}, \mathrm{n}=30\right.$ ) donors (Envigo, Indianapolis, IN, USA) in a sterile manner using flashing technique $(22,23)$. Harvested cells were filtered using $40 \mu \mathrm{m}$ strainer, purified by Histopaque 1083 (MiliporeSigma, St. Louis, MO, USA) and counted with 0.4\% Trypan Blue (ThermoFisher Scientific, Waltham, MA, USA).

\section{Fusion procedure}

BMC from ACI $\left(\mathrm{RT}^{\mathrm{a}}\right)$ and Lewis $\left(\mathrm{RT} 1^{1}\right)$ donors were stained using PKH26 (ACI) or PKH67 (Lewis) fluorescent dyes (MiliporeSigma). Staining was performed as previously reported $(22,24,25)$ with the adjusted staining time of $3 \mathrm{~min}$.

Next, PKH26 labeled ACI BMC and PKH67 labeled Lewis BMC were mixed and washed with RPMI 1640 medium without FBS. Fusion was performed as previously reported $(24,25)$ using $50 \% \mathrm{w} / \mathrm{v}$ polyethylene glycol 4000 (EMD, Burlington, MA, USA) and 16\% dimethyl sulfoxide (DMSO). PKH26/PKH67 labeled DRCC were selected using BD Special Order BD FACS Aria II. DRCC's purity $\left(1 \times 10^{5}\right.$ cells, $\left.n=3\right)$ were assessed using LSRFortessa cytometer (BD, Franklin Lakes, NJ, USA). DRCC's viability, diameter and circulatory index $(n=3)$ were measured by Trypan blue staining with Vi-CELL XR-Cell Viability Analyzer (Beckman Coulter, Brea, CA, USA).

\section{Confocal microscopy}

BMC controls and DRCC were fixed in 4\% paraformaldehyde (EMS, Hatfield, PA, USA) for 15 min. Images of PKH labeled cells mounted with VECTASHIELD Antifade Mounting Medium with DAPI (Vector Laboratories, Burlingame, CA, USA) were taken by TCS-SP upright confocal microscope with Retiga 2000R camera (Leica, Wetzlar, Germany) and ImagePro Plus (Media Cybernetics, Rockville, MD, USA).

\section{PCR}

DNA was isolated using DNeasy Blood \& Tissue Kit (QIAGEN, Hilden Germany USA) according to the manufacturer's instructions. PCR $(n=3)$ was performed as previously described (22).

\section{Colony forming unit (CFU) assay}

To assess proliferation and differentiation properties, 
BMC controls and DRCC ( $\mathrm{n}=3$ /group) were cultured in MethoCult ${ }^{\circledR}$ medium (Stemcell Technologies, Vancouver, Canada) according to manufacturer instructions. Photographs of CFU were taken using MZ16FA stereomicroscope equipped with Retiga cooled CCD camera (Leica).

\section{Flow cytometry}

Annexin V staining (BioLegend, San Diego, CA, USA) of BMC controls and DRCC $\left(1 \times 10^{6}, \mathrm{n}=3\right.$ /group $)$ was performed after sorting, at 24 hours and at 5 days after sorting according to the manufacturer's instruction (BioLegend) and evaluated by LSRFortessa and Flowjo software (BD). Gating strategy for Annexin V/Sytox blue staining evaluation was based on previously published twostage gating strategy (26).

Phenotype analysis: BMC controls and DRCC $\left(1 \times 10^{6}\right.$, $\mathrm{n}=3$ /group) blocked with Rat Fc Block (BD Biosciences, USA) for 5 min. were incubated with antibodies: CD3APC, CD45-APC-Cy7, CD4-APC-Cy7, CD90-Pacific Blue, CD11b/c-APC (Biolegend), CD8a-BV421, CD25APC, CD45RA-BV421 (BD Biosciences), or OX-82Biotin (ThermoFisher Scientific) in combination with Streptavidin-APC-Cy7 (BD Pharmingen) for 40 minat $4{ }^{\circ} \mathrm{C}$. Cells were assessed using LSR II analyzer (BD).

\section{Enzyme-linked immunosorbent assay (ELISA)}

The medium samples from cultures of DRCC in enriched StemSpan ${ }^{\circledR}$ SFEM medium were collected at days 1, 5 and 14. ELISA was performed in triplicates to assess the secretion of IL-2, IL-4, IL-10, TGFß1, IFN $\gamma$ and TNF $\alpha$ (ThermoFisher Scientific) according to manufacturer's instructions. Bio-Rad iMark Microplate Absorbance Reader (Bio-Rad Laboratories, Hercules, CA, USA) was used to acquire data.

\section{Mixed lymphocyte reaction}

Splenocytes isolated from 7-8 weeks old male Lewis and BN rats ( $\mathrm{n}=3$ /assay), were labeled with $3 \mu \mathrm{M}$ CellTrace ${ }^{\mathrm{TM}}$ Violet and applied as responder cells ( $2 \times 10^{5} /$ assay). Stimulator cells were irradiated (3000 cGy) using a 137Cs source (Gamma cell $^{\circledR} 3000$, Ottawa, ON, Canada). Phytohemagglutinin (PHA, $5 \mu \mathrm{g} / \mathrm{mL}$ ) was used for mitogen stimulation. DRCC were seeded at concentration of $1 \times 10^{4}, 1 \times 10^{5}$ and $1 \times 10^{6}$ cells. Mixed responder and stimulator cells were cultured in $200 \mu \mathrm{L}$ of "complete" RPMI 1640 medium containing 10\% FBA and $1 \mathrm{X}$ antibiotic/antimycotic solution (1XAAS, ThermoFisher Scientific) for 5 days.

\section{Hoechst 33342 staining}

To assess DRCC's ploidy ( $\mathrm{n}=3$ /assay), the DRCC were incubated with $10 \mu \mathrm{g} / \mathrm{mL}$ Hoechst 33342 dye for 45 minutes at $37^{\circ} \mathrm{C}$. Immediately after completion of staining and washing, samples were assessed by BD LSRFortessa and Flowjo software (BD).

\section{COMET assay}

COMET assay kit (Abcam, Cambridge, United Kingdom) assessed the DNA damage after cell fusion $(n=3)$. The isolated BMC, PKH labeled BMC and DRCC were processed according to manufacturer's instruction. Slides were assessed using MZ16FA stereomicroscope equipped with $10 \times$ and 20x objectives, Retiga 2000R camera (Leica). Fifty cells were evaluated in each gel using visual scoring system 0-4, from 0 (no tail) to 4 (all DNA in tail) with the average minimal score of 0 and average maximal of 200 "arbitrary units" (27).

\section{DRCC culturing}

DRCC ( $\mathrm{n}=3)$ were tested in the: (I) "complete" DMEM, (II “complete" RPMI 1640, (III) StemSpan ${ }^{\circledR}$ SFEM (Stemcell Technologies) medium with 1XAAS, and (IV) enriched StemSpan ${ }^{\circledR}$ SFEM medium containing 10\% FBS, 1XAAS and cytokine mix (28), including recombinant human acidic Fibroblast Growth Factor (aFGF, $10 \mathrm{ng} / \mathrm{mL}$ ), recombinant mouse Stem Cell Factor (SCF, $10 \mathrm{ng} / \mathrm{mL}$ ), recombinant mouse Thrombopoietin (TPO, $20 \mathrm{ng} / \mathrm{mL}$ ), recombinant mouse Insulin Growth Factor-II (IGF-II, $20 \mathrm{ng} / \mathrm{mL}$; R\&D Systems, Minneapolis, MN), 1XAAS (MiliporeSigma), Heparin $(10 \mu \mathrm{g} / \mathrm{mL}$, MiliporeSigma) and 10\% FBS (ThermoFisher Scientific). DRCC were cultured in standard conditions for 30 days. Trypan Blue and Sytox blue tested DRCC's number and viability.

\section{Reverse transcription PCR}

RNA from cultured DRCC $(\mathrm{n}=3)$ was isolated using TRIZOL ${ }^{\circledR}$ Reagent (ThermoFisher Scientific) and purified with RNeasy ${ }^{\circledR}$ Mini Kit according to the manufacturer's instructions. Concentration and quality of RNA was tested 
with NanoDrop ${ }^{\circledR}$ ND-1000 (ThermoFisher Scientific) and visual examination of $28 \mathrm{~S}$ and $18 \mathrm{~S}$ rRNA bands. RNA $(0.65 \mu \mathrm{g})$ was transcribed to cDNA using High Capacity cDNA Reverse Transcription Kit (Applied Biosystem) according to manufacturer's instruction. PCR was performed using Mastercycle epgradient PCR system (Eppendorf, Hamburg, Germany) for genes: CD11a (5'-GTTTCAAGGTCGCCTGCTTG-3', 5'-TGCCGTTCAGCTCGACAAAA-3'; 698bp), CD 18, (5'-CTGGCCCACAAACTTTCCGA-3', 5' - TA G C C A G A C T C A C A C C T G C A - 3'; $509 \mathrm{bp}), \quad \mathrm{CD} 31$ [1 $101 \mathrm{bp}$, (29)], C D 45 ( 5' - G A A G A C C C T C A C C T G C T C C T - 3'; 5'-GGATGTACTGGGCCTCCACT-3', $235 \mathrm{bp}$ ), CD90 (5'-GTGACCTTCGAGTCTCGGGC-3', 5'-TGGCTTGGAGGAAGGAGAGG-3'; 156bp), vimentin (5'-CCAGAGACGGACAGGTGATCA-3', 5'-CTTCTTGCTGGTACTGCGCC-3'; 99bp), collagen 1A1 (5'-TGGATTCCAGTTCGAGTATG-3', 5'-AGGTGATGTTCTGGGAGGCC-3'; 107 bp), fibronectin (5'-CGTCAGGCTTAGGCCAAGAC-3', 5'-ACGTTGCTTCATGGGGATCG-3'; 680bp) and $\beta$-actin [495bp, (30)] as reference gene. Amplification was carried out for 40 cycles in a total volume of $25 \mu \mathrm{L}$ containing Platinum ${ }^{\circledR}$ Blue PCR SuperMix (ThermoFisher Scientific), primers $(0.2 \mu \mathrm{M})$ and $0.2 \mu \mathrm{g}$ cDNA in standard conditions.

\section{Statistical analysis}

Statistical analysis was performed using Minitab software (OriginLab Corp. Northhampton, MA, USA). In vitro assays were performed in triplicates in three independent experiments with naïve and/or PKH labeled BMC as reference controls. Values are presented as mean $\pm \mathrm{SD}$. One-way ANOVA and general linear model followed by Tukey's post-hoc tests or Student T-test determined statistical significance at $\mathrm{P}<0.05$.

\section{Results}

\section{Confirmation of DRCC Creation}

The fusion procedure in combination with gating strategy allowed for selection of DRCC with efficacy of $77.7 \% \pm 9.1 \%$. The DRCC's chimeric state was confirmed using the overlapping PKH26/PKH67 labeling by confocal microscopy and the presence of MHC class I sequences specific for
ACI $\left(\mathrm{RT}^{\mathrm{a}}\right)$ and Lewis $\left(\mathrm{RT}^{1}{ }^{1}\right)$ donors in the DNA material of sorted DRCC (Figure 1A,B,C). DRCC presented $>95 \%$ purity, as confirmed by flow cytometry and $95.2 \% \pm 2.3 \%$ viability post-fusion, as confirmed by Trypan blue staining.

\section{Evaluation of apoptosis in cultured DRCC}

Annexin V staining, a marker of early apoptosis (Annexin $\mathrm{V}^{+} /$Sytox blue $)$showed no changes among the assessed samples of unstained ACI $(8.32 \% \pm 1.54 \%)$ and Lewis BMC $(7.43 \% \pm 1.4 \%)$, PKH26 labeled ACI $(8.4 \% \pm 0.95 \%)$ and PKH67 labeled Lewis BMC $(7.74 \% \pm 1.7 \%)$ and DRCC $(8.02 \% \pm 1.4 \%)$ at the fusion day (Figure $1 D)$. At $24 \mathrm{~h}$ post-fusion the percentage of Annexin $\mathrm{V}^{+} /$Sytox blue cells doubled in unstained ACI $(14.8 \% \pm 3 \%)$ and Lewis BMC $(18.3 \% \pm 2.6 \%, \mathrm{P}<0.003$ vs. 0 h), PKH26 labeled ACI $(11.3 \% \pm 1.6 \%)$ and PKH67 labeled Lewis BMC $(16.4 \% \pm 3.2 \%, \mathrm{P}<0.04$ vs. 0 h). The percentage of Annexin $\mathrm{V}^{+} /$Sytox blue ${ }^{-}$DRCC also increased to $38.4 \pm 3.1 \%(\mathrm{P}<0.001)$. Decrease in the number of early apoptotic DRCC to $28.3 \% \pm 2.5 \%(\mathrm{P}<0.006$ vs. $24 \mathrm{~h})$ was observed after 5 -day culture and was comparable to levels of apoptosis in samples of unstained ACI $(20.9 \% \pm 3.55 \%, \mathrm{P}<0.004$ vs. $24 \mathrm{~h})$ and Lewis BMC $(25.3 \% \pm 2.3 \%, \mathrm{P}<0.02$ vs. $24 \mathrm{~h})$ as well as PKH26 labeled ACI $(21.4 \% \pm 2.32 \%, \mathrm{P}<0.0008$ vs. $24 \mathrm{~h})$ and PKH67 labeled Lewis BMC (25.2\% $\pm 3.95 \%, \mathrm{P}<0.04$ vs. $24 \mathrm{~h})$.

Annexin $\mathrm{V}^{+} /$Sytox blue ${ }^{+}$staining (Figure $1 E$ ) showed an increase in the number of late apoptotic cells after PKH26 and PKH67 BMC staining and fusion $(3.55 \% \pm 1.3 \%$, $4.8 \% \pm 1.5 \%$ and $5.78 \% \pm 1.2 \%$, respectively), compared to unstained ACI and Lewis BMC $(1.6 \% \pm 0.96 \% *$ and $1.9 \% \pm 1.1 \% *$, respectively; $\mathrm{P}<0.02$ vs. DRCC). After 24 -hour culturing, the number of late apoptotic cells significantly increased in samples of unstained ACI $(13.6 \% \pm 1.4 \% *, \mathrm{P}<0.02$ vs. DRCC) and Lewis BMC $(14.5 \% \pm 2.5 \% *, \mathrm{P}<0.03$ vs. DRCC) as well as PKH26 labeled ACI $(17.7 \% \pm 3.1 \% *)$ and PKH67 labeled Lewis $(15.4 \% \pm 3.6 \% *)$ BMC and DRCC $\left(22.6 \% \pm 2.5 \% *,{ }^{*} \mathrm{P}<0.001\right.$ $v s .0 \mathrm{~h})$. After 5 -day culturing the late apoptotic cells number decreased in all samples (unstained ACI BMC 3.6\% $1.2 \%$ *\#, unstained Lewis BMC- $6 \% \pm 4.6 \%$ *,, PKH26 labeled ACI

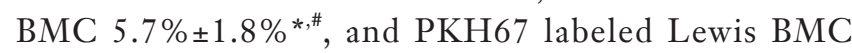
$5.3 \% \pm 2.4 \%{ }^{* *}$ and DRCC $13.9 \% \pm 2.6 \%^{\#} ;{ }^{*} \mathrm{P}<0.04$ vs. DRCC) compared to results obtained at $24 \mathrm{~h}\left({ }^{\#} \mathrm{P}<0.04\right)$.

\section{Confirmation of hematopoietic phenotype of DRCC}

The average BMC diameters were $8.9 \pm 0.14 \mu \mathrm{m}$ for 


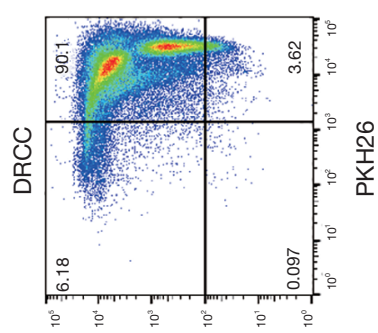

$\angle 9 H$ प्रd

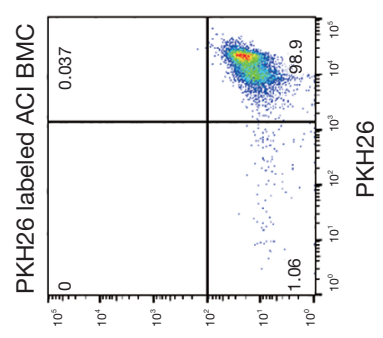

L9HYXd

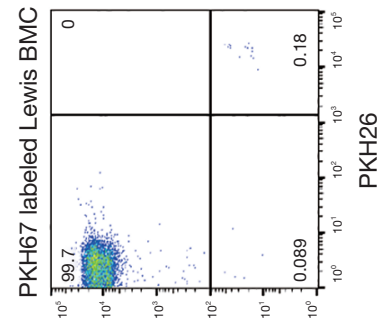

$\angle 9 H$ Y्रd
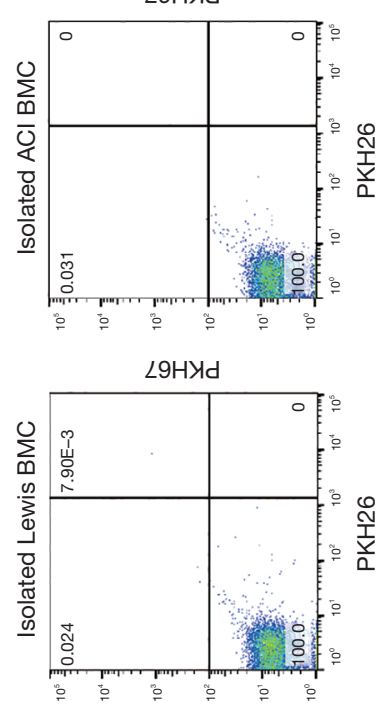

L9Hत्रd

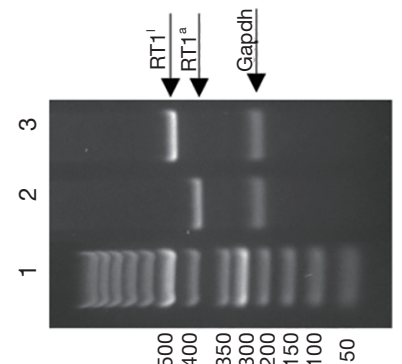

U

0
O্
ণ

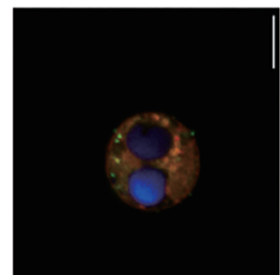

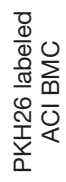

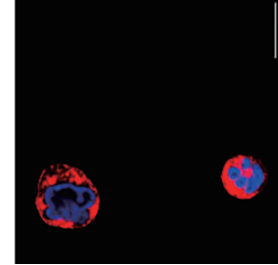

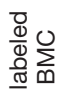

움롱

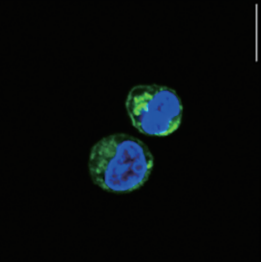

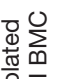

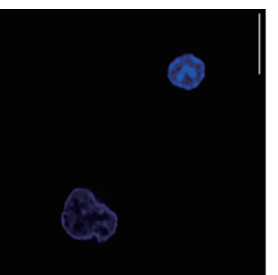

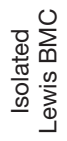

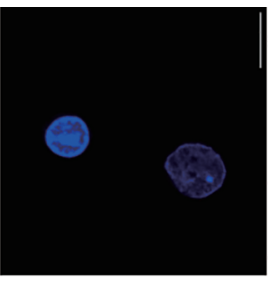

$\infty$

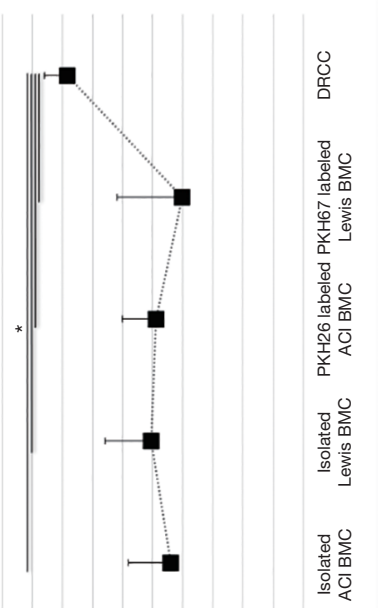

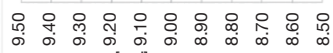

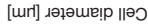

Ш

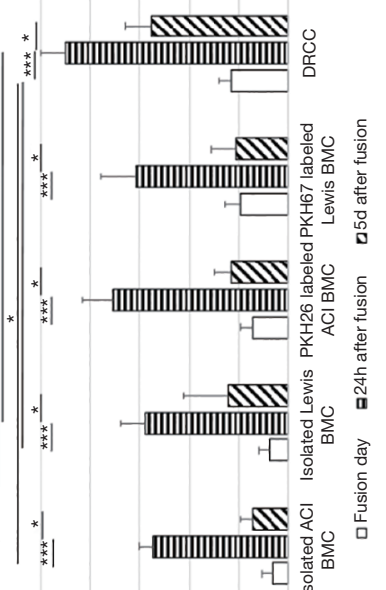

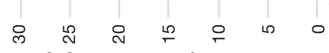

ш

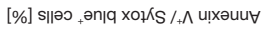

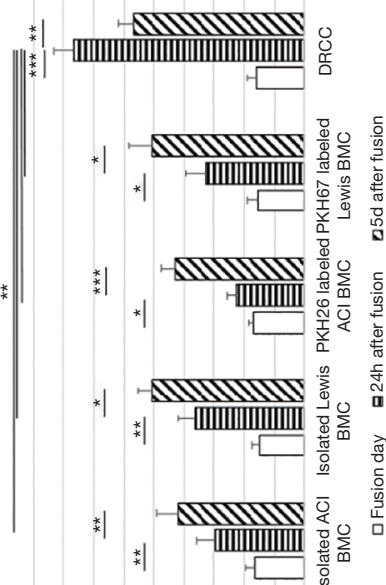

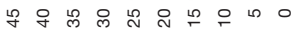

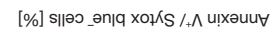

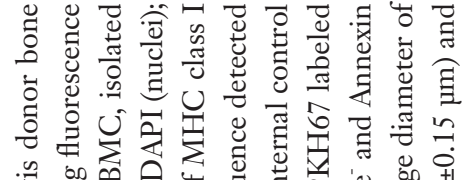

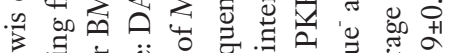

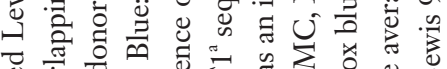

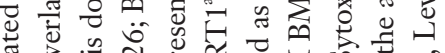

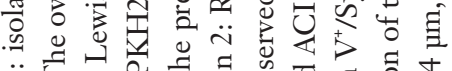

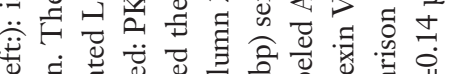

응

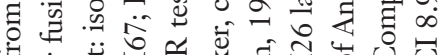

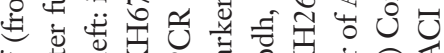

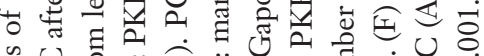

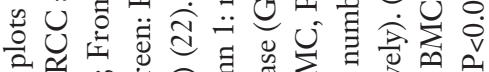

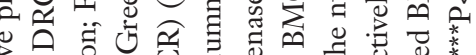

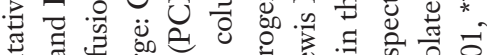

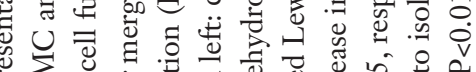

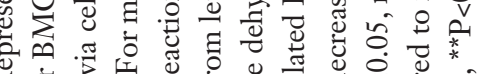

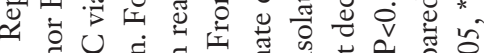

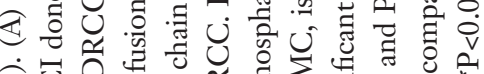
$\hat{0}$

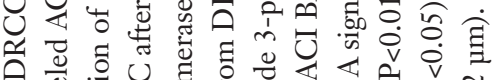

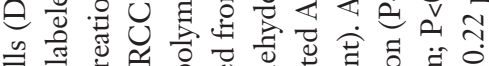

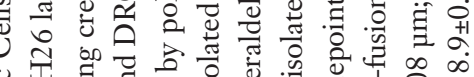

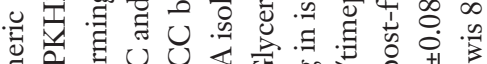

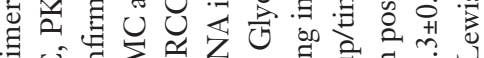

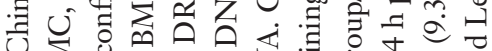

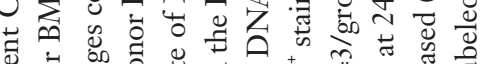

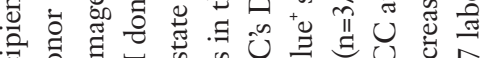

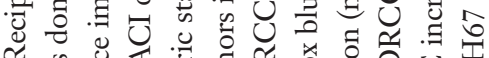

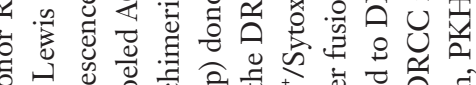

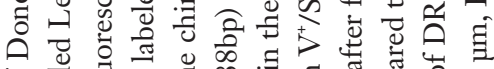

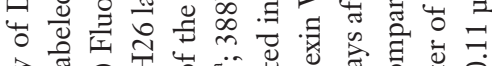

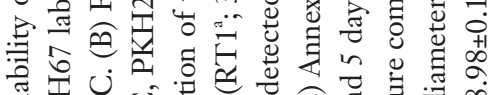

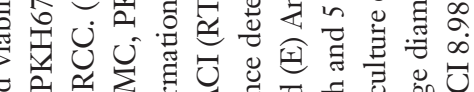

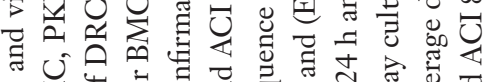
过诺

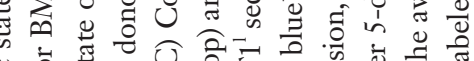

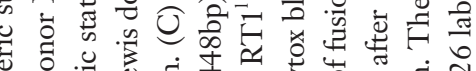

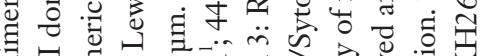

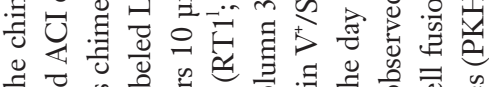

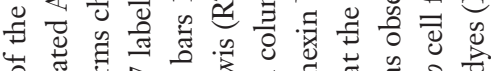
4 舟 5.

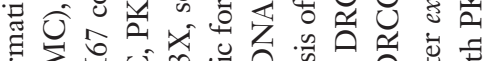
青造论 6

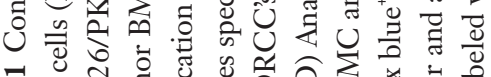

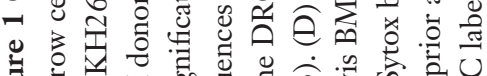

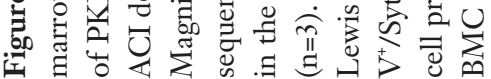


unstained ACI, $9 \pm 0.15 \mu \mathrm{m}$ for unstained Lewis BMC, $8.98 \pm 0.11 \mu \mathrm{m}$ for PKH26 labeled ACI and $8.9 \pm 0.22 \mu \mathrm{m}$ for PKH67 labeled Lewis BMC, while the average diameter of DRCC was $9.3 \pm 0.08 \mu \mathrm{m}(\mathrm{P}<0.05$, Figure $1 F)$. This result was in line with a shift of forward (FSC) vs. side scatter (SSC) plots of BMC prior to and after fusion. There was no statistically significant change in circularity index between the BMC controls and DRCC.

Phenotype characterization confirmed the low number of CD3 (<1\%), CD4 (<7\%) and CD8 ( $<1 \%)$ positive cells within DRCC population (Figure $2 A, B)$. DRCC presented $98.2 \% \pm 1.9 \%$ of $\mathrm{CD} 45$ and $46.4 \% \pm 2.06 \%$ of CD 90 positive cells. The average expression of CD11b/c was $25 \% \pm 2.45 \%$, CD $45 \mathrm{RA}$ was $28.3 \% \pm 1.2 \%$ and $\mathrm{OX}-82$ was $13.3 \% \pm 2.6 \%$. The percentage of CD4/CD25 positive DRCC was $3.2 \pm 0.84$. No statistically significant differences were observed in the expression patterns of the assessed markers between BMC controls and DRCC (Figure 2B).

\section{Confirmation of DRCC's proliferation and differentiation}

CFU assay confirmed that DRCC can produce the same types (Figure 2C) and comparable number of colonies as BMC controls. The average total number of colonies produced by unstained BMC was $63.2 \pm 19.7$ (Lewis) and $83.8 \pm 30.9$ (ACI), PKH67 labeled Lewis BMC was $63.6 \pm 21$, PKH26 labeled ACI BMC was $74.8 \pm 27$ and DRCC was $56.2 \pm 6.6(\mathrm{P}>0.05)$. Following CFU assay, 79\% of DRCC presented immature progenitor granulocyte/macrophage phenotype, as confirmed by CD 90 and CD $11 \mathrm{~b} / \mathrm{c}$ staining, and $\mathrm{MHC}$ class I specific for fusion donors was present in DRCC derived DNA (Figure 2D,E).

\section{Confirmation of tolerogenic properties of DRCC}

MLR assay showed significantly lower $(7.8 \% \pm 1.54 \%)$ response to DRCC compared to controls stimulated by PHA $(60.2 \% \pm 9.08 \%)$ and the $3^{\text {rd }}$ party allogenic T-cells $(57.23 \% \pm 9.44 \%, \mathrm{P}<0.05$, Figure $3 A, B, C, D, E)$. The autologous T-cells control using irradiated Lewis T-lymphocytes showed $2.88 \% \pm 1.27 \%$ proliferation rate.

\section{DRCC secretes pro-tolerogenic IL-10 and TGF 1}

ELISA confirmed that DRCC secrete IL-10 at levels of $16.79 \pm 0.46 \mathrm{pg} / \mathrm{mL}$ at $24 \mathrm{~h}, 31.47 \pm 0.4 \mathrm{pg} / \mathrm{mL}$ at 5 days and $11.58 \pm 0.15 \mathrm{pg} / \mathrm{mL}$ at 14 days, as compared to medium $(3.09 \pm 1.95 \mathrm{pg} / \mathrm{mL})$ and BMC controls $(16.4 \pm 0.75 \mathrm{pg} / \mathrm{mL})$.
The DRCC's secretion of TGF $\beta 1$ reached $129.8 \pm 13.2 \mathrm{pg} / \mathrm{mL}$ at $24 \mathrm{~h}, 139.5 \pm 12.56 \mathrm{pg} / \mathrm{mL}$ at 5 days and $185.2 \pm 5.2 \mathrm{pg} / \mathrm{mL}$ at 14 days and increased significantly compared to the medium $(108.1 \pm 13.2 \mathrm{pg} / \mathrm{mL})$ and BMC $(109.5 \pm 14.7 \mathrm{pg} / \mathrm{mL})$ controls (Figure $3 F$ ). The elevated level of TGF $\beta 1$ detected in the medium control is due to the presence of FBS in the enriched StemSpan ${ }^{\circledR}$ SFEM medium. FBS contains a high level of latent TGF $\beta$, which is detected by ELISA assay. Latent TGF $\beta$ does not bind to TGF $\beta$ receptors (31). ELISA did not detect IL-2, $\mathrm{TNF} \alpha, \mathrm{IFN} \gamma$ or IL-4 in any of collected samples.

\section{Confirmation of low polyploidy of DRCC}

Hoechst33342 indicated that the average percent of tetraploid $(4 \mathrm{~N}) \mathrm{DRCC}$ was $3.1 \% \pm 0.2 \%$ compared to isolated BMC $(0.96 \% \pm 0.1 \%$, Figure $4 A)$. The low occurrence rate of multinucleated cells was also detected by confocal microscopy post-fusion (Figure 1B).

\section{COMET assay confirms lack of DNA damage post-fusion}

Visual scoring of COMET assay of ACI and Lewis BMC, PKH26 labeled ACI and PKH67 labeled Lewis BMC, and DRCC showed negligible number of cells scored as 1 $(0.2 \pm 0.4,0.3 \pm 0.7,0.1 \pm 0.7,0.2 \pm 0.4$ and $0.1 \pm 0.3$, respectively) compared to BMC control pre-treated with $20 \mu \mathrm{M}$ etoposide $(167 \pm 19.4, \mathrm{P}<0.01$, Figure $4 B)$. The representative fluorescent images of COMET assay performed in alkaline solution of the etoposide pre-treated BMC control (positive control), ACI and Lewis BMC, PKH26 labeled ACI and PKH67 labeled Lewis BMC, and DRCC are presented in Figure $4 C$ confirming no damage to the DNA of either BMC prior to fusion as well as DRCC after fusion procedure.

\section{DRCC cultures}

In all of the tested media $>80 \%$ of DRCC remained nonadherent to the plastic. DRCC survived 14-18 days in the StemSpan ${ }^{\circledR}$ SFEM medium without FBS, 16-21 days in "complete" DMEM and RPMI media and 26-28 days in the enriched StemSpan ${ }^{\circledR}$ SFEM medium. The enriched StemSpan ${ }^{\circledR}$ SFEM medium presented the lowest percentage of necrotic DRCC $(13.9 \% \pm 2.6 \%, \mathrm{P}<0.05)$ at day 5 of culturing compared to $26.5 \% \pm 6.8 \%$ of necrotic DRCC in "complete" DMEM, $25.6 \% \pm 1.9 \%$ in "complete" RPMI and $33.6 \% \pm 4.6 \%$ in Stemspan ${ }^{\circledR}$ SFEM medium $(\mathrm{n}=3 /$ group). The DRCC reached plateau at day 12 of culturing 


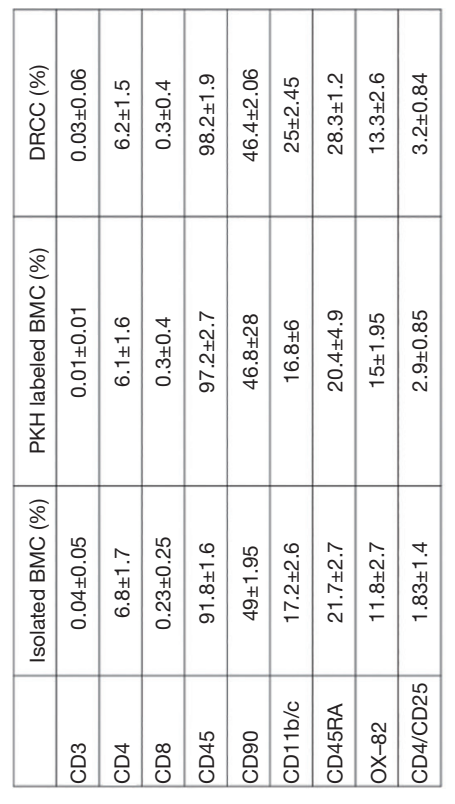

$\infty$
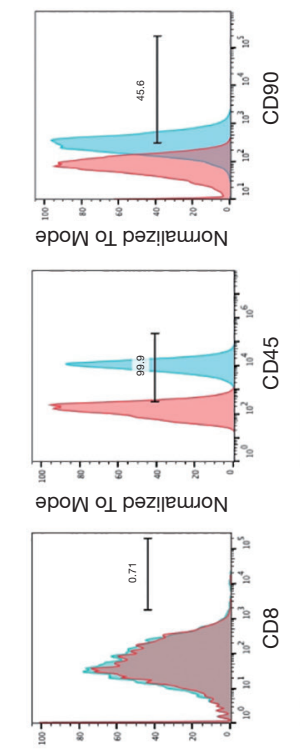

әpow 이 pəz!|euxoN

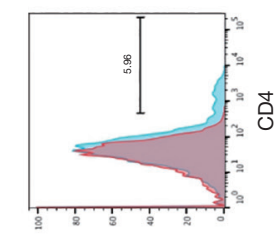

әроW 니 pəz!|ешлоN

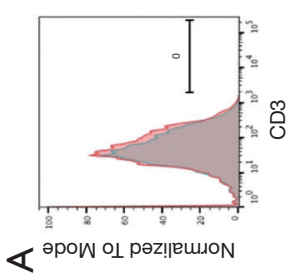

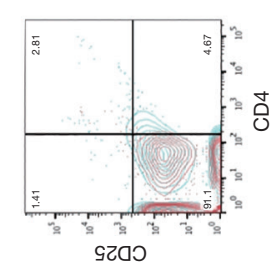
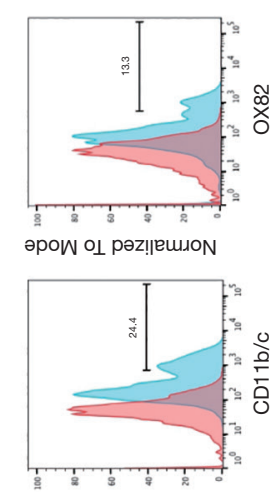

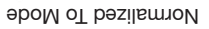

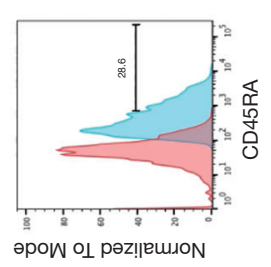

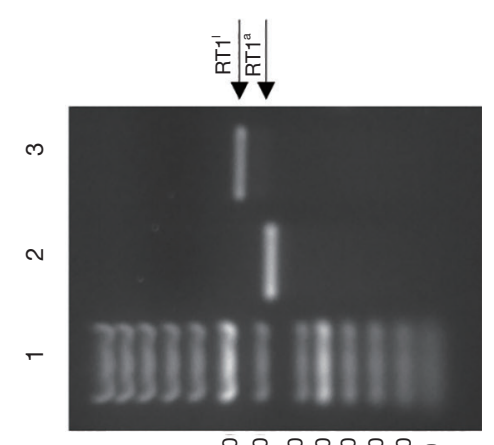

ш
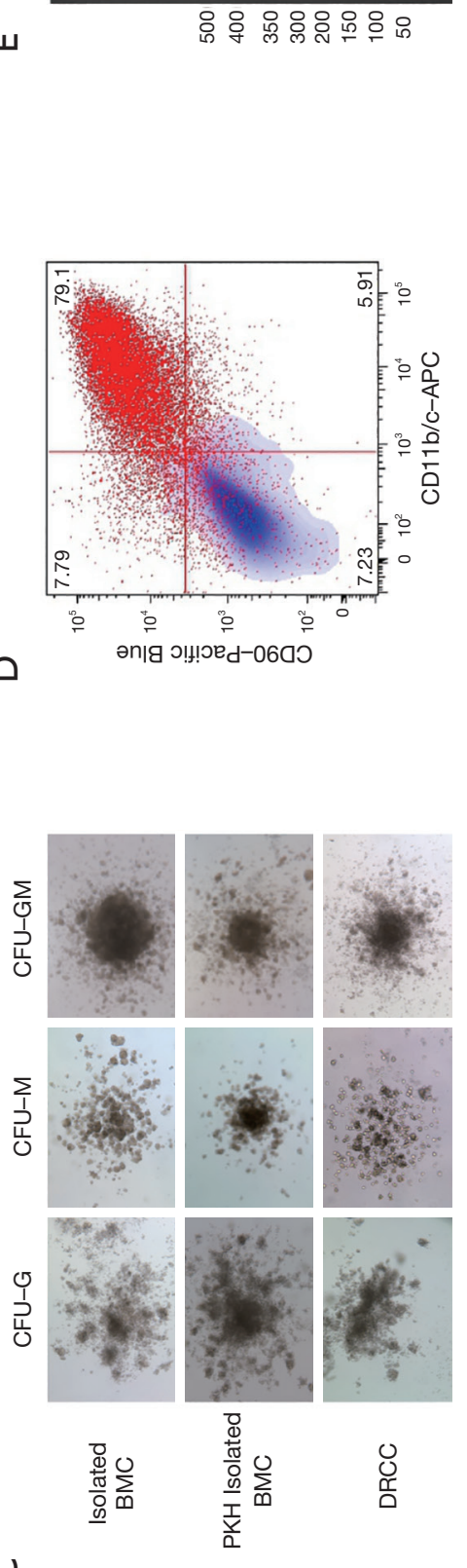

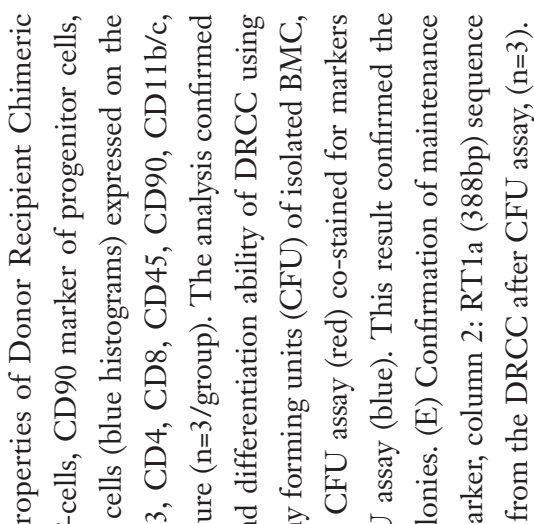

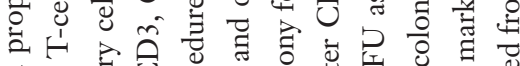

б

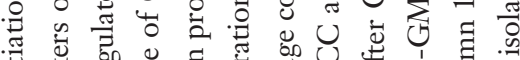

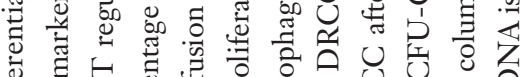

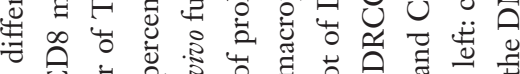
U

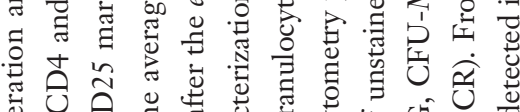

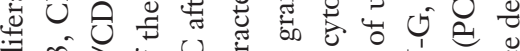

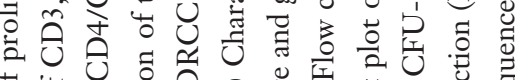
प्山े च

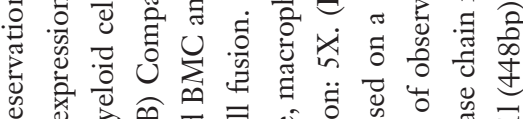

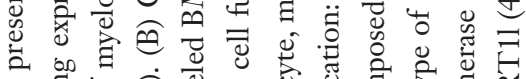

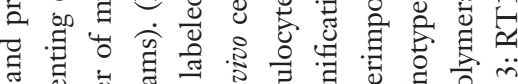

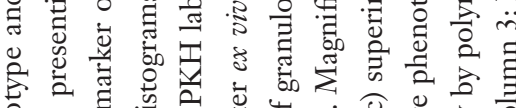

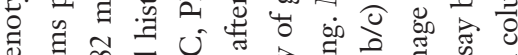

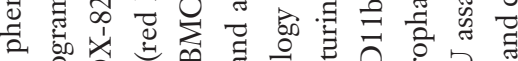

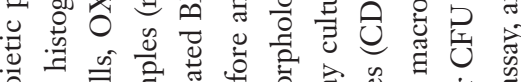

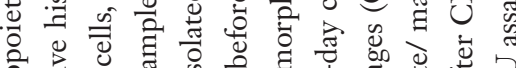

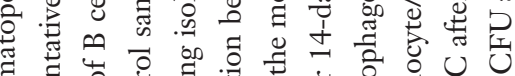

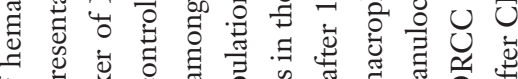
पे ช थ

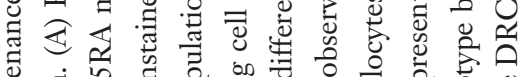

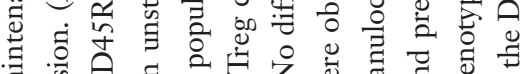

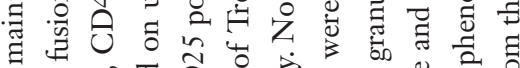

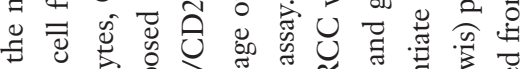

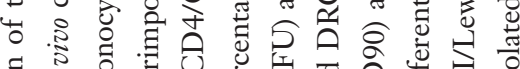

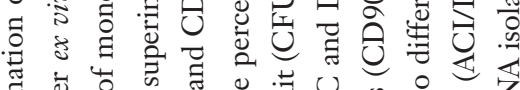

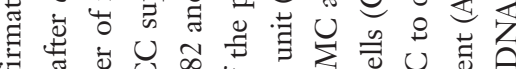

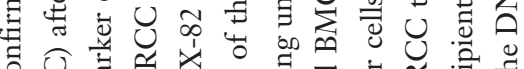
○े

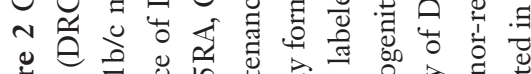

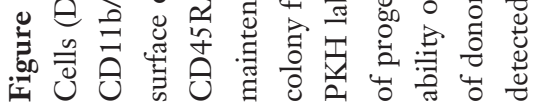


A

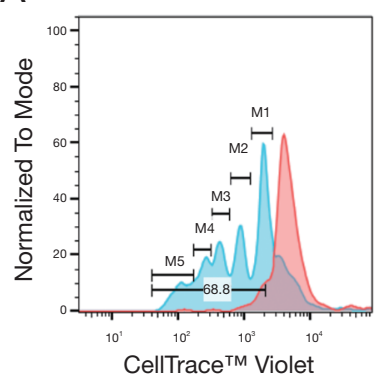

B

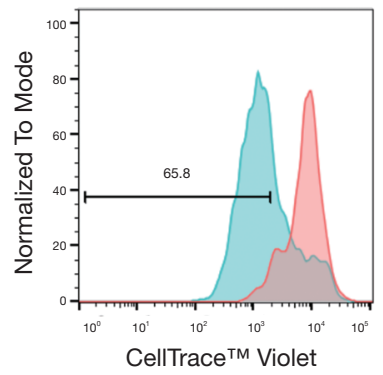

E

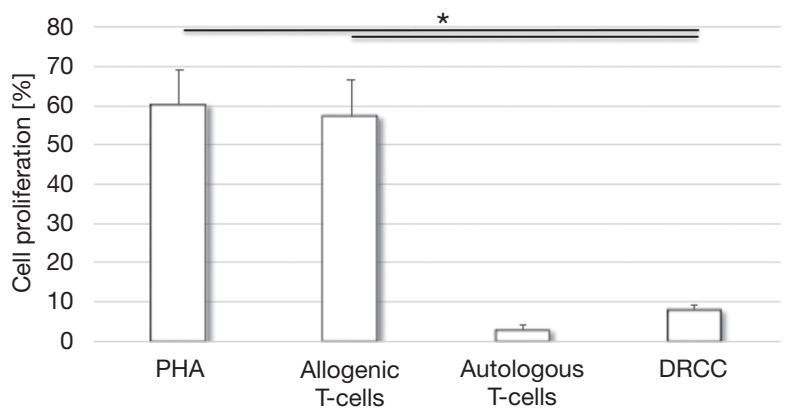

C

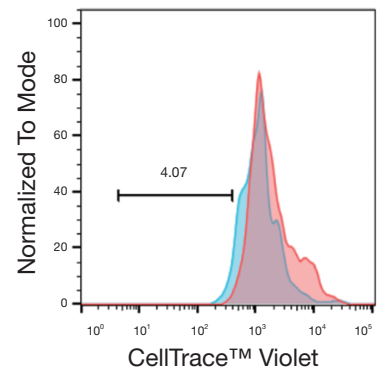

D

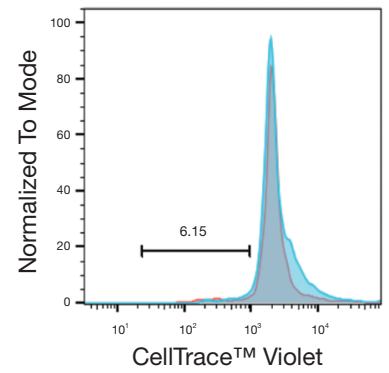

$\mathrm{F}$

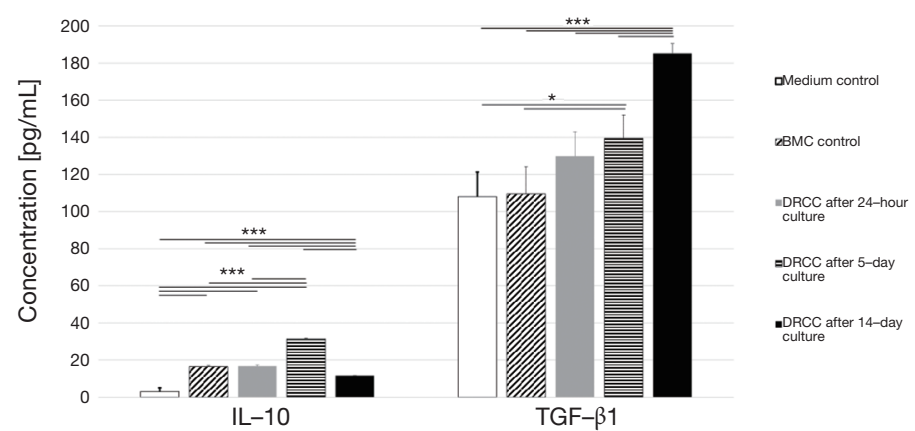

Figure 3 Analysis of immunogenicity of Donor Recipient Chimeric Cells (DRCC) using one-way mixed lymphocyte reaction (MLR). Representative histograms assessing lymphocyte proliferation based on dilution of the CellTrace ${ }^{\mathrm{TM}}$ Violet dye; from left: (A) proliferating responder T-cells stimulated with phytohemagglutinin (PHA), (B) 3rd party allogenic T-cells, (C) autologous T-cells, (D) DRCC stimulated responder T-cell proliferation (blue histograms) superimposed on negative controls of non-proliferating responder T-cells in culture media for 5 days (red histograms). (E) Quantitative comparison of the results of MLR assays ( $\mathrm{n}=3 /$ group) showing decreased response of Lewis T lymphocytes to DRCC compared to PHA and 3rd party allogenic T-cell controls, ${ }^{*} \mathrm{P}<0.05$. (F) Quantitative comparison of secretion of IL-10 and TGF $\beta 1$ by DRCC at 24 h, 5 days and 14 days after ex vivo cell fusion by ELISA showing the highest secretion of IL-10 at 5 days post-fusion $(31.47 \pm 0.4 \mathrm{pg} / \mathrm{mL})$ and TGF $\beta 1$ at 14 days post-fusion $(185.2 \pm 5.2 \mathrm{pg} / \mathrm{mL})$. From left: white bar: Medium control, diagonal pattern bar: BMC control, grey bar: DRCC after 24-hour culture, horizontal pattern bar: DRCC after 5-day culture, black bar: DRCC after 14-day culture. ${ }^{*} \mathrm{P}<0.05,{ }^{* * *} \mathrm{P}<0.001$

which was followed by decrease in the number of cells up to day 28 of the culture (Figure 4D). After 5-day culturing $>80 \%$ of DRCC presented strong PKH26/PKH67 labeling sufficient to distinguish DRCC from unstained cells (Figure $4 E)$. Strong expression of CD90, CD31, CD45, CD18 and CD11a confirmed preservation of DRCC's hematopoietic progenitor/stem cell profile (Figure 4F).

\section{Discussion}

Multiple studies described involvement of cell fusion in tissue regeneration $(6,12,24,25,32,33)$ encouraging development of fusion-based cell lines and therapies for research and clinical applications (2,34-40). The presence of donor/ recipient cells observed in the clinical BMT studies (41-43) was explained by spontaneous fusion of donor HSC with cells of BMT recipient or by trogocytosis, a process of intercellular transfer of membrane patches or proteins (44-47). Trogocytosis modifies function of stem, progenitor and differentiated immune cells (48-51), including transfer of antigens Fc receptors or major histocompatibility complex (MHC) molecules from macrophages to lymphocytes $(44,52)$, capture of recipient's MHC by donor thymocytes $(53,54)$, and transfer of MHC from recipient's splenocytes to donor T-cells (55). The presence of hematopoietic cells presenting the donor and recipient MHC class I molecules was observed by Siemionow's group in a rat BMT model $(23,56)$. These donor/recipient cells created in vivo were used to induce tolerance in a hemiface allotransplantation model. Although, the therapy provided promising results by extending the 
A

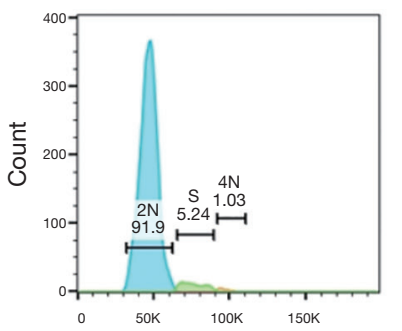

DNA content-Hoechst 33342 stain

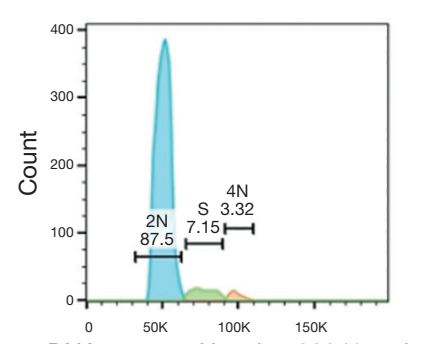

DNA content-Hoechst 33342 stain
B

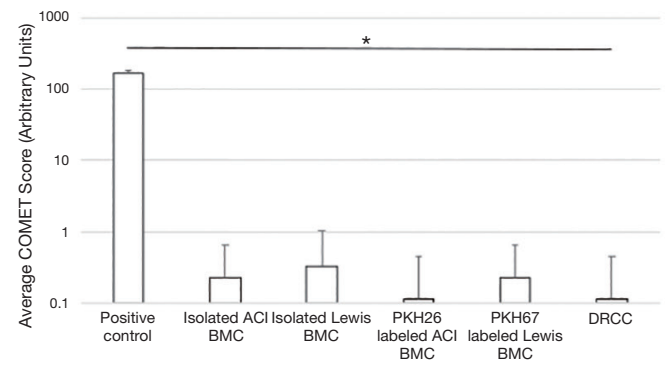

C

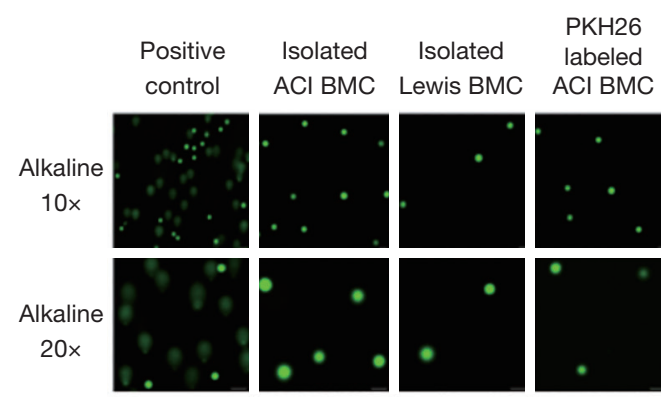

$\mathrm{E}$

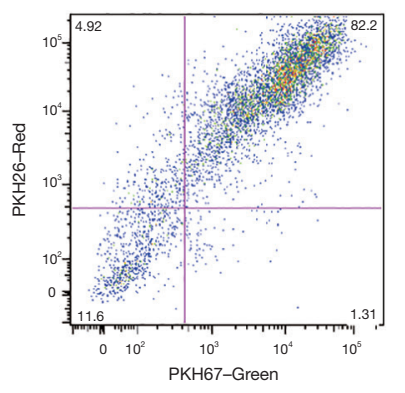

PKH67

\section{labeled} Lewis BMC
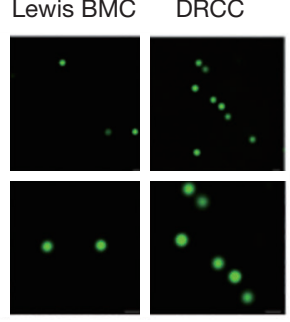

D

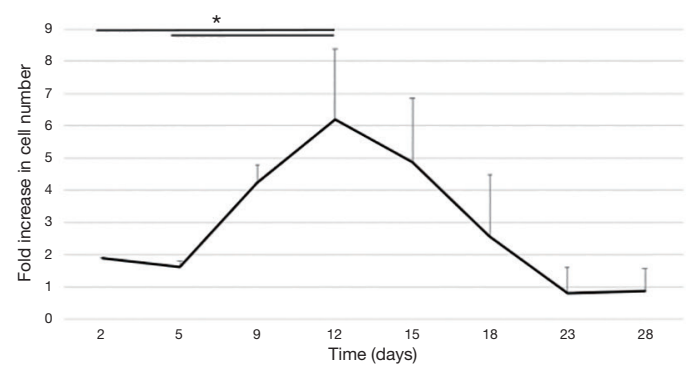

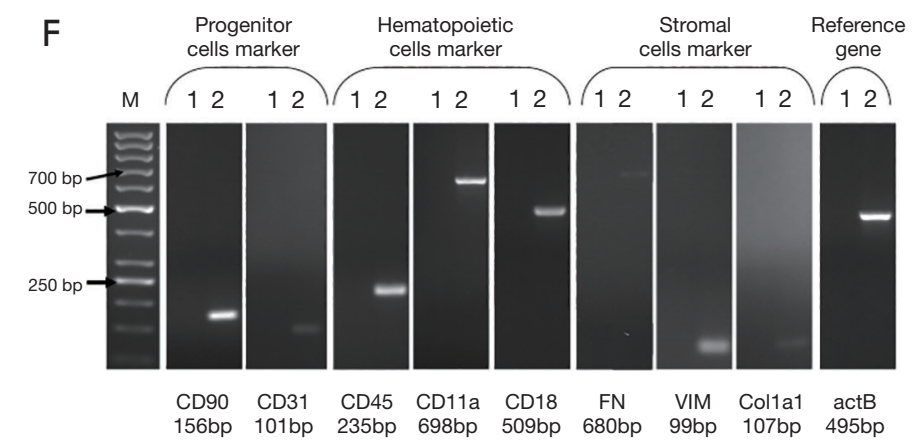

Figure 4 Assessment of polyploidy and DNA integrity of Donor Recipient Chimeric Cells (DRCC) and characterization of DRCC after long-term culturing. (A) Representative histograms Hoechst 33342 staining comparing the polyploidy of: (from left) isolated BMC and DRCC. The isolated BMC samples contained $0.96 \% \pm 0.1 \%$ of tetraploid cells $(4 \mathrm{~N})$ and in comparison, the majority of DRCC $(>86 \%)$ were diploid ( $2 \mathrm{~N}$ ) while the $4 \mathrm{~N}$ cells constituted $3.1 \% \pm 0.2 \%$. $2 \mathrm{~N}$ : diploid cells, S: DNA synthesis, $4 \mathrm{~N}$ : tetraploid cells. (B) The quantitative analysis of Comet assay (Single Cell Gel Electrophoresis - SCGE assay) confirming lack of genotoxicity by absence of DNA damage in DRCC following ex vivo cell fusion procedure. The visual scoring analysis of the Comet assay tails proved the absence of genotoxicity of cell fusion procedure on BMC and DRCC, ${ }^{*} \mathrm{P}<0.05$. Rat naïve BMC treated with $20 \mu \mathrm{M}$ etoposide overnight served as positive controls. (C) Representative fluorescence images of Comet assay showing DNA damage in $20 \mu \mathrm{M}$ etoposide treated BMC (positive controls) and confirming lack of DNA damage in isolated ACI and Lewis BMC controls, PKH labeled ACI and Lewis BMC controls and DRCC. Green - Vista Green DNA Staining Solution (nucleus stain); Magnification 10× and 20x, scale bars $10 \mu \mathrm{m}$. (D) Analysis of proliferation kinetics of DRCC cultured in enriched Stemspan ${ }^{\circledR}$ SFEM medium. Absolute cell counts $(\mathrm{n}=3)$ at each timepoint were normalized with the number of seeded cell and proliferation was expressed in the fold increase. DRCC confirmed statistically significant maximal proliferation counts at day 12 after fusion $\left({ }^{*} \mathrm{P}<0.05\right)$. (E) Flow cytometry plot confirming the maintenance of PKH26/PKH67 labeling of DRCC after 5-day culturing in enriched Stemspan ${ }^{\circledR}$ SFEM medium. (F) Comparison of hematopoietic and stromal cell markers expressed by DRCC after 5 -day culturing in enriched Stemspan ${ }^{\circledR}$ SFEM medium as assessed by reverse transcription polymerase chain reaction (rtPCR). Representative images of PCR products of progenitor cells marker: CD90, CD31, hematopoietic cells markers: CD45, CD11a, CD18 and stromal cells markers: fibronectin (FN), vimentin (VIM), and Collagen 1a1 (Col1a1). M: marker of the PCR reaction product size, 1: RNA control; 2: cDNA from cultured DRCC, actB: beta actin served as a reference gene for the PCR reaction. 
VCA survival, the technique of obtaining DRCC was not clinically applicable. Thus, we applied ex vivo cell fusion to create DRCC therapy to facilitate allograft-specific tolerance.

In our proof of concept study, the feasibility of cell fusion procedure and creation of DRCC were confirmed based on fluorescence tracing dyes and the presence of genomic MHC class I sequences specific for each BMC donor. We established fusion protocol for DRCC creation achieving $77.7 \% \pm 9.1 \%$ efficiency with $>95 \%$ purity and $>90 \%$ viability. As expected, fusion increased the average DRCC diameter but did not affect DRCC circularity.

The increased percentage of Annexin $\mathrm{V}^{+}$/Sytox blue and Annexin $\mathrm{V}^{+} /$Sytox blue $\mathrm{e}^{+} \mathrm{DRCC}$ at $24 \mathrm{~h}$ after fusion compared to BMC controls could have resulted from DRCC processing time, sorting conditions, or application of PEG/DMSO fusion solution (57). However, at day 5 of culturing, the number of early apoptotic DRCC (Annexin $\mathrm{V}^{+} /$Sytox blue $e^{-}$decreased and was comparable to BMC controls. The recovery of DRCC population and DRCC's capability for differentiation in vitro were supported by the CFU assay results. This suggests capability of DRCC for engraftment and chimerism induction in vivo. Evaluation of DRCC proliferative potential in long-term cultures indicated that in contrast to hybridoma cells and tumor cell lines presenting uncontrollable proliferation $(58,59)$, DRCC exhibited limited number of cell divisions.

The phenotype comparison between BMC controls and DRCC proved that ex vivo fusion does not change the values of lymphoid and myeloid markers with DRCC characterized predominantly by hematopoietic (CD45) stem/progenitor cells (CD90), expressing myeloid (CD11b/ c, OX-82) and B cell markers (CD45RA). This indicates the capability of DRCC to generate multilineage chimerism in vivo comparable to BMT.

DRCC's presented pro-tolerogenic properties with increased secretion of pro-tolerogenic cytokines IL-10 and TGF $\beta 1$ and lack of Th1 inflammatory cytokines. IL10 and TGF $\beta$ participate in multiple regulatory processes by stimulation of Treg, Breg, monocytes/macrophages and DC (60). IL-10 decreases expression of MHC-II, costimulatory molecules and IL-12 while TGF $\beta$ reduces lymphocyte proliferation and deactivation of killer T-cells $(61,62)$.

DRCC presented significantly lower immunogenicity compared to PHA and allogenic cell controls. Any transplanted cells which are not identical to the recipient, have potential to trigger the recipient's immune response (63). Thus, despite its' low immunogenicity, DRCC still may initiate the recipient's immune response in vivo. Therefore, introduction of short-term IS may be required during in vivo DRCC testing. The immature phenotype of DRCC combined with low immunogenicity and secretion of IL-10 and TGF $\beta 1$, confirms pro-tolerogenic profile of DRCC population which suggests that in vivo DRCC may have the ability to avoid the immune cells' recognition and engraft more efficiently without recipient's conditioning.

Although PEG is a nonmutagenic compound (64) inhibiting oncogenesis $(65,66)$, the safety of DRCC was assessed based on DRCC ploidy and potential damage to DRCC's DNA. DRCC presented low frequency of tetraploid cells ( $4 \mathrm{~N}: 3.1 \% \pm 0.2 \%)$. No multinucleated DRCC $(>4 \mathrm{~N})$ were observed following fusion procedure. Cells presenting higher DNA ploidy have been reported in studies exploring fusion created tumor cells and were associated with problems with irregular and unrestricted cell proliferation (67). The diploid state of the majority of the DRCC $(2 \mathrm{~N}>96 \%)$ combined with the lack of synkaryons or polyploidy exceeding $4 \mathrm{~N}$ adds to the safety profile of DRCC for in vivo application. Moreover, negligible degradation of the DNA material during the visual COMET scoring demonstrated limited genotoxicity of fusion procedure.

Cytokine enriched StemSpan ${ }^{\circledR}$ SFEM medium (28) supported the longest DRCC survival with a six-fold cell number increase. Cytokines were added to the medium to prevent apoptosis and stimulate the symmetric selfrenewal of DRCC stem cells in long-term cultures (68-72). Moreover, the enriched medium allowed DRCC to maintain hematopoietic phenotype. Based on the DRCC growth phase, proliferation rate and the peak of the pro-tolerogenic cytokine expression, the 5-day of DRCC culturing was selected as optimal for DRCC harvesting and application as a tolerance inducing therapy.

This study confirmed both, the feasibility of DRCC creation via ex vivo cell fusion as well as highlighted the pro-tolerogenic properties of DRCC in vitro. The protolerogenic DRCC profile in combination with DRCC proliferation and differentiation potential which is comparable to BMC will facilitate engraftment and survival of DRCC in vivo. This proof-of-concept study provides basis for future in vivo testing of the immunomodulatory effects of DRCC therapy in preclinical experimental transplantation models.

\section{Conclusions}

This study established and characterized a novel hematopoietic donor/recipient specific DRCC. Due to 
decreased immunogenicity and pro-tolerogenic cytokine expression, DRCC represent a promising approach as a personalized supportive therapy for the chimerism and tolerance induction in BMT, solid organ and VCA transplantation.

\section{Acknowledgments}

The authors thank Aleksandra Klimczak PhD, Adam Bobkiewicz MD, PhD, Arkadiusz Jundzill MD, $\mathrm{PhD}$, and Cleveland Clinic flow cytometry and imaging cores for technical support in the study.

Funding: This work was supported by funding from Department of Defense Armed Force Institute of Regenerative Medicine (AFIRM, W81XWH-08-2-0034).

\section{Footnote}

Reporting Checklist: The authors have completed the ARRIVE reporting checklist. Available at http://dx.doi. org/10.21037/sci-2020-044

Conflicts of Interest: All authors have completed the ICMJE uniform disclosure form (available at http://dx.doi. org/10.21037/sci-2020-044). The authors have no conflicts of interest to declare.

Ethical Statement: The authors are accountable for all aspects of the work in ensuring that questions related to the accuracy or integrity of any part of the work are appropriately investigated and resolved. Experiments were performed under a project license (NO.: 2012-0841) granted by Institutional Animal Care and Use Committee (IACUC) of Cleveland Clinic, in compliance with 'Principles of laboratory animal care' formulated by the National Society for Medical Research and the 'Guide for the care and use of laboratory animal resources' formulated by the US NIH guidelines for the care and use of animals.

Open Access Statement: This is an Open Access article distributed in accordance with the Creative Commons Attribution-NonCommercial-NoDerivs 4.0 International License (CC BY-NC-ND 4.0), which permits the noncommercial replication and distribution of the article with the strict proviso that no changes or edits are made and the original work is properly cited (including links to both the formal publication through the relevant DOI and the license). See: https://creativecommons.org/licenses/by-nc-nd/4.0/.

\section{References}

1. Rickert CG, Markmann JF. Current state of organ transplant tolerance Curr Opin Organ Transplant 2019;24:441-50.

2. Lluis F, Cosma MP. Cell-fusion-mediated somatic-cell reprogramming: a mechanism for tissue regeneration. J Cell Physiol 2010;223:6-13.

3. LaBarge MA, Blau HM. Biological progression from adult bone marrow to mononucleate muscle stem cell to multinucleate muscle fiber in response to injury. Cell 2002;111:589-601.

4. Wang $\mathrm{X}$, Willenbring $\mathrm{H}$, Akkari $\mathrm{Y}$, et al. Cell fusion is the principal source of bone-marrow-derived hepatocytes. Nature 2003;422:897-901.

5. Alvarez-Dolado M, Pardal R, Garcia-Verdugo JM, et al. Fusion of bone-marrow-derived cells with Purkinje neurons, cardiomyocytes and hepatocytes. Nature 2003;425:968-73.

6. Vassilopoulos G, Wang PR, Russell DW. Transplanted bone marrow regenerates liver by cell fusion. Nature 2003;422:901-4.

7. Weimann JM, Johansson CB, Trejo A, et al. Stable reprogrammed heterokaryons form spontaneously in Purkinje neurons after bone marrow transplant. Nat Cell Biol 2003;5:959-66.

8. Nygren JM, Jovinge S, Breitbach M, et al. Bone marrowderived hematopoietic cells generate cardiomyocytes at a low frequency through cell fusion, but not transdifferentiation. Nat Med 2004;10:494-501.

9. Camargo FD, Finegold M, Goodell MA. Hematopoietic myelomonocytic cells are the major source of hepatocyte fusion partners. J Clin Invest 2004;113:1266-70.

10. Willenbring H, Bailey AS, Foster M, et al. Myelomonocytic cells are sufficient for therapeutic cell fusion in liver. Nat Med 2004;10:744-8.

11. Rizvi AZ, Swain JR, Davies PS, et al. Bone marrowderived cells fuse with normal and transformed intestinal stem cells. Proc Natl Acad Sci U S A 2006;103:6321-5.

12. Johansson CB, Youssef S, Koleckar K, et al. Extensive fusion of haematopoietic cells with Purkinje neurons in response to chronic inflammation. Nat Cell Biol 2008; 10:575-83.

13. Powell AE, Anderson EC, Davies PS, et al. Fusion between Intestinal epithelial cells and macrophages in a cancer context results in nuclear reprogramming. Cancer Res 2011;71:1497-505.

14. Sanges D, Romo N, Simonte G, et al. Wnt/beta-catenin 
signaling triggers neuron reprogramming and regeneration in the mouse retina. Cell Rep 2013;4:271-86.

15. Dittmar T, Zanker KS. Tissue Regeneration in the Chronically Inflamed Tumor Environment: Implications for Cell Fusion Driven Tumor Progression and Therapy Resistant Tumor Hybrid Cells. Int J Mol Sci 2015;16:30362-81.

16. Zito F, Lampiasi N, Kireev I, et al. United we stand: Adhesion and molecular mechanisms driving cell fusion across species. Eur J Cell Biol 2016;95:552-62.

17. Lu X, Kang Y. Efficient acquisition of dual metastasis organotropism to bone and lung through stable spontaneous fusion between MDA-MB-231 variants. Proc Natl Acad Sci U S A 2009;106:9385-90.

18. Ramakrishnan M, Mathur SR, Mukhopadhyay A. Fusion-derived epithelial cancer cells express hematopoietic markers and contribute to stem cell and migratory phenotype in ovarian carcinoma. Cancer Res 2013;73:5360-70.

19. Nagler C, Hardt C, Zanker KS, et al. Co-cultivation of murine BMDCs with 67NR mouse mammary carcinoma cells give rise to highly drug resistant cells. Cancer Cell Int 2011;11:21.

20. Terada N, Hamazaki T, Oka M, et al. Bone marrow cells adopt the phenotype of other cells by spontaneous cell fusion. Nature 2002;416:542-5.

21. Ying QL, Nichols J, Evans EP, et al. Changing potency by spontaneous fusion. Nature 2002;416:545-8.

22. Siemionow M, Rampazzo A, Gharb BB, et al. The reversed paradigm of chimerism induction: Donor conditioning with recipient-derived bone marrow cells as a novel approach for tolerance induction in vascularized composite allotransplantation. Microsurgery 2016;36:676-83.

23. Hivelin M, Klimczak A, Cwykiel J, et al. Immunomodulatory Effects of Different Cellular Therapies of Bone Marrow Origin on Chimerism Induction and Maintenance Across MHC Barriers in a Face Allotransplantation Model. Arch Immunol Ther Exp (Warsz) 2016;64:299-310.

24. Siemionow M, Cwykiel J, Heydemann A, et al. Creation of Dystrophin Expressing Chimeric Cells of Myoblast Origin as a Novel Stem Cell Based Therapy for Duchenne Muscular Dystrophy. Stem Cell Rev Rep 2018;14:189-99.

25. Siemionow M, Cwykiel J, Heydemann A, et al. Dystrophin Expressing Chimeric (DEC) Human Cells Provide a Potential Therapy for Duchenne Muscular Dystrophy. Stem Cell Rev Rep 2018;14:370-84.

26. van Genderen H, Kenis H, Lux P, et al. In vitro measurement of cell death with the annexin A5 affinity assay. Nat Protoc 2006;1:363-7.

27. Collins AR. The comet assay for DNA damage and repair: principles, applications, and limitations. Mol Biotechnol 2004;26:249-61.

28. Zhang CC, Lodish HF. Murine hematopoietic stem cells change their surface phenotype during ex vivo expansion. Blood 2005;105:4314-20.

29. Wragg A, Mellad JA, Beltran LE, et al. VEGFR1/CXCR4positive progenitor cells modulate local inflammation and augment tissue perfusion by a SDF-1-dependent mechanism. J Mol Med (Berl) 2008;86:1221-32.

30. Chen JA, Chang LR, Feng GM, et al. Stress alters the expression of aquaporins in cultured rat intestinal epithelial cells. Exp Ther Med 2015;10:1967-72.

31. Oida T, Weiner HL. Depletion of TGF- $\beta$ from fetal bovine serum. J Immunol Methods 2010;362:195-8.

32. Gussoni E, Soneoka Y, Strickland CD, et al. Dystrophin expression in the $\mathrm{mdx}$ mouse restored by stem cell transplantation. Nature 1999;401:390-4.

33. Siemionow M, Malik M, Langa P, et al. Cardiac Protection after Systemic Transplant of Dystrophin Expressing Chimeric (DEC) Cells to the mdx Mouse Model of Duchenne Muscular Dystrophy. Stem Cell Rev Rep 2019;15:827-41.

34. Akasaki Y, Kikuchi T, Homma S, et al. Antitumor effect of immunizations with fusions of dendritic and glioma cells in a mouse brain tumor model. J Immunother 2001;24:106-13.

35. Weise JB, Maune S, Gorogh T, et al. A dendritic cell based hybrid cell vaccine generated by electrofusion for immunotherapy strategies in HNSCC. Auris Nasus Larynx 2004;31:149-53.

36. Koido S, Homma S, Hara E, et al. Regulation of tumor immunity by tumor/dendritic cell fusions. Clin Dev Immunol 2010;2010:516768.

37. Cho HC, Kashiwakura Y, Marban E. Creation of a biological pacemaker by cell fusion. Circ Res 2007;100:1112-5.

38. Quijada P, Salunga HT, Hariharan N, et al. Cardiac Stem Cell Hybrids Enhance Myocardial Repair. Circ Res 2015;117:695-706.

39. Guo-Parke H, McCluskey JT, Kelly C, et al. Configuration of electrofusion-derived human insulin-secreting cell line as pseudoislets enhances functionality and therapeutic utility. J Endocrinol 2012;214:257-65.

40. Koido S, Gong J. Cell fusion between dendritic cells and whole tumor cells. Methods Mol Biol 2015;1313:185-91. 
41. Weimann JM, Charlton CA, Brazelton TR, et al. Contribution of transplanted bone marrow cells to Purkinje neurons in human adult brains. Proc Natl Acad Sci U S A 2003;100:2088-93.

42. Cogle CR, Yachnis AT, Laywell ED, et al. Bone marrow transdifferentiation in brain after transplantation: a retrospective study. Lancet 2004;363:1432-7.

43. Silk AD, Gast CE, Davies PS, et al. Fusion between hematopoietic and epithelial cells in adult human intestine. PLoS One 2013;8:e55572.

44. Bona C, Robineaux R, Anteunis A, et al. Transfer of antigen from macrophages to lymphocytes.

II. Immunological significance of the transfer of lipopolysaccharide. Immunology 1973;24:831-40.

45. Hudrisier D, Bongrand P. Intercellular transfer of antigenpresenting cell determinants onto T cells: molecular mechanisms and biological significance. FASEB J 2002;16:477-86.

46. Caumartin J, Lemaoult J, Carosella ED. Intercellular exchanges of membrane patches (trogocytosis) highlight the next level of immune plasticity. Transpl Immunol 2006; 17:20-2.

47. Smyth LA, Afzali B, Tsang J, et al. Intercellular transfer of MHC and immunological molecules: molecular mechanisms and biological significance. Am J Transplant 2007;7:1442-9.

48. Caumartin J, Favier B, Daouya M, et al. Trogocytosisbased generation of suppressive NK cells. EMBO J 2007;26:1423-33.

49. LeMaoult J, Caumartin J, Daouya M, et al. Immune regulation by pretenders: cell-to-cell transfers of HLA-G make effector T cells act as regulatory cells. Blood 2007;109:2040-8.

50. Yamanaka N, Wong CJ, Gertsenstein M, et al. Bone marrow transplantation results in human donor blood cells acquiring and displaying mouse recipient class I MHC and CD45 antigens on their surface. PLoS One 2009;4:e8489.

51. Davis DM. Intercellular transfer of cell-surface proteins is common and can affect many stages of an immune response. Nat Rev Immunol 2007;7:238-43.

52. Lee ST, Paraskevas F. Macrophage--T cell interactions. I. The uptake by T cells of Fc receptors released from macrophages. Cell Immunol 1978;40:141-53.

53. Sharrow SO, Ozato K, Sachs DH. Phenotypic expression of I-A and I-E/C subregion determinants on murine thymocytes. J Immunol 1980;125:2263-8.

54. Sharrow SO, Mathieson BJ, Singer A. Cell surface appearance of unexpected host MHC determinants on thymocytes from radiation bone marrow chimeras. J Immunol 1981;126:1327-35.

55. Lorber MI, Loken MR, Stall AM, et al. I-A antigens on cloned alloreactive murine $\mathrm{T}$ lymphocytes are acquired passively. J Immunol 1982;128:2798-803.

56. Cwykiel J, Siemionow M. In vivo chimera model: Creation of Primery and Secondary Chimera. In: Siemionow M, editor. Plastic and Reconstructive Surgery. London: Springer-Verlag; 2015. p. 581-93.

57. Roy HK, Gulizia J, DiBaise JK, et al. Polyethylene glycol inhibits intestinal neoplasia and induces epithelial apoptosis in Apc(min) mice. Cancer Lett 2004;215:35-42.

58. Grigsby RV, Fairbairn D, O'Neill KL. Differential DNA damage detected in hybridomas. Hybridoma 1993;12:755-61.

59. Kohler G, Milstein C. Continuous cultures of fused cells secreting antibody of predefined specificity. 1975 . Biotechnology 1992;24:524-6.

60. Sabat R, Grutz G, Warszawska K, et al. Biology of interleukin-10. Cytokine Growth Factor Rev 2010;21:331-44.

61. de Waal Malefyt R, Haanen J, Spits H, et al. Interleukin 10 (IL-10) and viral IL-10 strongly reduce antigen-specific human $\mathrm{T}$ cell proliferation by diminishing the antigenpresenting capacity of monocytes via downregulation of class II major histocompatibility complex expression. J Exp Med 1991;174:915-24.

62. D'Andrea A, Aste-Amezaga M, Valiante NM, et al. Interleukin 10 (IL-10) inhibits human lymphocyte interferon gamma-production by suppressing natural killer cell stimulatory factor/IL-12 synthesis in accessory cells. J Exp Med 1993;178:1041-8.

63. Wood KJ, Issa F, Hester J. Understanding Stem Cell Immunogenicity in Therapeutic Applications. Trends Immunol 2016;37:5-16.

64. Wangenheim J, Bolcsfoldi G. Mouse lymphoma L5178Y thymidine kinase locus assay of 50 compounds. Mutagenesis 1988;3:193-205.

65. Corpet DE, Parnaud G, Delverdier M, et al. Consistent and fast inhibition of colon carcinogenesis by polyethylene glycol in mice and rats given various carcinogens. Cancer Res 2000;60:3160-4.

66. Bailon P, Won CY. PEG-modified biopharmaceuticals. Expert Opin Drug Deliv 2009;6:1-16.

67. Nagy G, Kiraly G, Turani M, et al. Cell trivision of hyperploid cells. DNA Cell Biol 2013;32:676-84.

68. Matsunaga T, Kato T, Miyazaki H, et al. Thrombopoietin promotes the survival of murine hematopoietic long-term 
reconstituting cells: comparison with the effects of FLT3/ FLK-2 ligand and interleukin-6. Blood 1998;92:452-61.

69. Petit-Cocault L, Volle-Challier C, Fleury M, et al. Dual role of $\mathrm{Mpl}$ receptor during the establishment of definitive hematopoiesis. Development 2007;134:3031-40.

70. de Haan G, Weersing E, Dontje B, et al. In vitro generation of long-term repopulating hematopoietic stem cells by

doi: 10.21037/sci-2020-044

Cite this article as: Cwykiel J, Madajka-Niemeyer M, Siemionow M. Development of Donor Recipient Chimeric Cells of bone marrow origin as a novel approach for tolerance induction in transplantation. Stem Cell Investig 2021;8:8. fibroblast growth factor-1. Dev Cell 2003;4:241-51.

71. Zhang CC, Lodish HF. Insulin-like growth factor 2 expressed in a novel fetal liver cell population is a growth factor for hematopoietic stem cells. Blood 2004;103:2513-21.

72. Hassan HT, Zander A. Stem cell factor as a survival and growth factor in human normal and malignant hematopoiesis. Acta Haematol 1996;95:257-62. 